\title{
Improvement in phosphorus use efficiency of corn crop by amending the soil with sulfur and farmyard manure
}

\author{
Abu El-Eyuoon Abu Zied Amin \\ ${ }^{1}$ Assiut University, Faculty of Agriculture, Soils and Water Department, Assiut, Egypt
}

\begin{abstract}
The use of organic manure is proposed to reduce the use of chemical fertilizers, as well as to add sulfur $(S)$ into the soil so that the phosphate use efficiency may be improved by maize crop. This field experiment was conducted during 2014 at Assiut city, Assiut governorate, Egypt to study the effect of sulfur and farmyard manure (FYM) on phosphorus availability, grain yield and phosphorus use efficiency of corn (Zea mays L. cv Single Hybrid 10). Randomized complete block design was followed with three replications. Four treatments viz SP= superphosphate, $S P+S=$ superphosphate + sulfur, $S P+F Y M=$ superphosphate +farmyard manure and $S P+F Y M+S=$ superphosphate + farmyard manure + sulfur were tested. The soil analysis after corn harvest showed that the Olsen $P$ of the soil improved with applying sulfur or farmyard manure and their mixture in presence of superphosphate. Adding farmyard manure with superphosphate enhanced grain yield of corn plants by $44.6 \%$ as well as the application of superphosphate with farmyard manure and sulfur increased the grain yield by $44.2 \%$ compared to the $S P$. The results in this study showed that amending soil by farmyard manure and sulfur with superphosphate improved phosphorus use efficiency in comparison with superphosphate alone.
\end{abstract}

Keywords: Superphosphate, grain yield, phosphorus uptake, recovery efficiency

\section{Introduction}

Egypt is located in the arid and semi-arid regions. Where most soils are considered being alkaline with soil $\mathrm{pH}$ greater than 7, calcium is predominant cation which reacts with phosphate ion and converts it into dicalcium and tricalcium phosphate and hydroxyapatite. One of the problems in alkaline soils when adding phosphate fertilizers is that the soluble phosphate turns to insoluble compounds of low availabilty to plants (Brady and Weil, 1999). Generally, the arid and semi-arid regions are poor in the organic matter content because of high temperature and low rainfall. Therefore we have to make up the shortfall in organic material by adding organic fertilizer. The application of manure is widely practiced to increase the productivity of soils that contains inadequate levels of organic carbon. The organic fertilizers applied to the soil enhanced soil fertility which release nutrients, maintain aggregate stability and permeability of the soil as well as improve biological activity in the soil (Adediran et al., 2005; Edmeades, 2003). The utilization of organic manures in soil fertilization caused the reduction of the chemical phosphorus fertilizers use. In some countries such as Switzerland, chemical phosphorus fertilizers import decreased by $66 \%$ because of using organic manures (Frossard et al., 2009). The addition of organic manures with inorganic phosphate fertilizer was led to increasing the availability and solubility of applied phosphate in the soil and improving the soil productivity (Agbenin and Igbokwe, 2006). Also, (Garg and Bahl 2008) reported that the addition of organic manures to soil increased Olsen $P$ due to the mineralization of organic manures. Thiobacillus bacteria contribute in the biological oxidation of sulfur producing sulphuric acid which leads to dissolving phosphorus from rock phosphate (Bhatti and Yawar, 2010). Corn (Zea mays L.) is the third most important crop in the world after wheat and rice. It is also one of the major cereal crops in Egypt, so it has importance to human and animal feeding. Increasing levels of sulfur up to $60 \mathrm{~kg} \mathrm{~S} \mathrm{ha}^{-1}$ significantly enhanced the grain yield of maize (Khan et al., 2006). The objectives of this study are to investigate the effect of sulfur and farmyard manure application on phosphorus availability, phosphorus use efficiency by corn plants and grain yield of corn.

\section{Materials and Methods}

\section{Field experiment}

This study was carried out during 2014 season at Assiut city, Assiut governorate to examine the effect of sulfur and farmyard manure on phosphorus use efficiency by corn plants (Zea mays L. cv Single Hybrid 10). The physical and chemical properties of the soil under study are presented in (Table 1). The experiment was designed as a randomized complete block with four treatments and three replications. These treatments were $\mathrm{SP}=$ superphosphate, $\mathrm{SP}+\mathrm{S}=$

\footnotetext{
*Email: abueleyuoon.amin@aun.edu.eg
} 
superphosphate+sulfur,SP+FYM= superphosphate+farmyard manure and $\mathrm{SP}+\mathrm{FYM}+\mathrm{S}=$ superphosphate + farmyard manure + sulfur. The superphosphate $\left(15 \% \mathrm{P}_{2} \mathrm{O}_{5}\right)$, sulfur and farmyard manure were applied at level of $240 \mathrm{~kg} \mathrm{ha}^{-1}, 476 \mathrm{~kg}$ $\mathrm{ha}^{-1}$ and $20 \mathrm{t} \mathrm{ha}^{-1}$, respectively. The potassium fertilizer was applied in one dose of $120 \mathrm{~kg} \mathrm{~K}_{2} \mathrm{SO}_{4} \mathrm{ha}^{-1}$. The additions of superphosphate fertilizer, elemental sulfur, farmyard manure and potassium fertilizer were before one week from cultivation and added through broadcast method. The elemental sulfur treatments were inoculated with Thiobacillus bacteria to motivate oxidation of elementals, were added in liquid form. The experimental unit area was $11.2 \mathrm{~m}^{2}$ (4 x $2.8 \mathrm{~m}$ ) with three rows per plot and the space between the rows was $0.75 \mathrm{~m}$. The level of corn was $24 \mathrm{~kg}$ $\mathrm{ha}^{-1}$ and corn grains were sown on June $5^{\text {th }} 2014$. Grains were sown in holes at space of $30 \mathrm{~cm}$ between each of them. After the germination the plants were thinned to one plant in hill. The nitrogen fertilizer was added to soil at level $286 \mathrm{~kg}$ $\mathrm{N} \mathrm{ha}^{-1}$ as Urea (46.5\%) and applied in two doses after 14 and 42 days from sowing. Corn plants were harvested after 110 days from planting and grain yield was recorded. The weight of grain yield was estimated for each plot separately. Soil samples were taken from each plot after the harvest for phosphorus analysis.

\section{Soil and plant analysis}

The particle size distribution of this soil was determined by the pipette method (Jackson, 1973). Moreover, the organic carbon (OC) was determined by the Walkley-Black dichromate oxidation method (Jackson, 1973). Soil $\mathrm{pH}$ was determined with glass electrode in a $1: 1$ (soil: water) suspension and the electrical conductivity (EC) was measured of 1:2.5 soil: water extract by an electrical conductivity meter (Baruah and Barthakur, 1997). Calcium carbonate $\left(\mathrm{CaCO}_{3}\right)$ was estimated using a volumetric calcium carbonate calcimeter (Jackson, 1973). Exchangeable cations were measured with the ammonium acetate replacing method (Baruah and Barthakur, 1997). Olsen $\mathrm{P}$ was extracted using $0.5 \mathrm{M} \mathrm{NaHCO} 3$ at $\mathrm{pH} 8.5$ according to Olsen et al. (1954). Total phosphorus in shoot and grain of corn plants has been appreciated by the digestion of the samples with a $2: 1$ of $\mathrm{HNO}_{3}: \mathrm{HClO}_{4}$ acid mixture (Morais and Rabelo, 1986). Phosphorus in the extracts was measured colorimetrically by the chlorostanous phosphomolybdic acid method in sulphuric acid system (Jackson, 1973).

\section{Calculation of phosphorus uptake and use efficiency by corn plants}

Phosphorus uptake and use efficiency by corn plants (Zea mays L.) were calculated as follows according to (Baligar et al., 2001; Dobermann, 2005; Hussein, 2009):

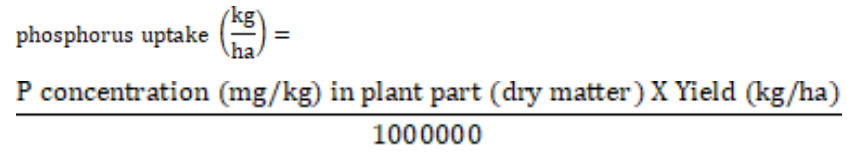

Partial factor productivity of applied phosphorus $\left(\mathrm{PFP}_{\mathrm{P}}\right)$ or phosphorus use efficiency (PUE)

$\mathrm{PFP}_{\mathrm{p}}=\frac{\left.\text { (Grain yield at applied } \frac{\mathrm{kg}}{\mathrm{ha}}\right)}{\left(\text { Amount of phosphorus applied } \mathrm{kg} \frac{\mathrm{P}_{2} \mathrm{~B}_{5}}{\mathrm{ha}}\right)}=$
$\mathrm{kg}$ grain $/ \mathrm{kg} \mathrm{P}_{2} \mathrm{O}_{5}$
Crop recovery efficiency of applied phosphor

$\mathrm{RE}_{\mathrm{p}}=$

$\frac{\left.\text { (Total P uptake at applied P } \frac{\mathrm{kg}}{\mathrm{ha}} \text {-Total P uptake atcontrol or no } \mathrm{P} \frac{\mathrm{kg}}{\mathrm{haz}}\right)}{\left.\text { (Amount of phosphorus fertilizer } \mathrm{P}_{2} \mathrm{~kg} \frac{\mathrm{P}_{2} \mathrm{~B}_{5}}{\mathrm{hal}}\right)}=$

$\mathrm{kg} / \mathrm{kg} \mathrm{P}_{2} \mathrm{O}_{5}$

Where: increase of phosphorus uptake $(\mathrm{kg}) /$ applied $\mathrm{P}_{2} \mathrm{O}_{5}$ ( $\mathrm{kg})$

\section{Statistical analysis}

Data collected were analyzed statistically using MSTAT program and the least significant difference (LSD) was used to compare treatment means at $p \leq 0.05$ level of significance (Steel and Torrie, 1982).

\section{Results}

\section{Phosphorus availability (OIsen P)}

In the present study, the application of sulfur and farmyard manure in presence of superphosphate to the clay soil caused significant increases in the available phosphorus after harvesting corn plants compared to adding superphosphate alone treatment (Table 2). The available phosphorus increased from $12.4 \mathrm{mg} \mathrm{kg}^{-1}$ when the superphosphate was added alone to $22.5 \mathrm{mg} \mathrm{kg}^{-1}$ using sulfur and farmyard manure in the presence of superphosphate.

\section{Grain yield and total phosphorus uptake of corn}

A significant increase in the grain yield of corn was recorded as a result of applying farmyard manure and sulfur with inorganic $\mathrm{P}$ fertilizer, in compare to that of the superphosphate alone (Table 2). Adding superphosphate with farmyard manure enhanced the grain yield from 4003.3 with SP alone treatment to $5790.2 \mathrm{~kg} \mathrm{ha}^{-1}$. However, superphosphate applied with farmyard manure and sulfur increased the grain yield from 4003.3 to $5774.6 \mathrm{~kg} \mathrm{ha}^{-1}$. Thus, the additions of farmyard manure with sulfur, or each one individually in the presence of superphosphate caused significant increases in the total phosphorus uptake by corn plants compared to the superphosphate alone treatment (Table 2). The total phosphorus uptake enhanced from 20.5 
$\mathrm{kg} \mathrm{ha}^{-1}$ with using superphosphate alone treatment to 30.4 $\mathrm{kg} \mathrm{ha}{ }^{-1}$ at the addition of farmyard manure with superphosphate as well as the superphosphate application with farmyard manure and sulfur raised the total phosphorus uptake from 20.5 to $29.1 \mathrm{~kg} \mathrm{ha}^{-1}$.

Table 1: Characteristics of the soil and farmyard manure under study

\begin{tabular}{|c|c|}
\hline \multicolumn{2}{|c|}{ Soil } \\
\hline Property & Value \\
\hline Clay $\left(\mathrm{g} \mathrm{kg}^{-1}\right)$ & 454.0 \\
\hline Silt $\left(\mathrm{g} \mathrm{kg}^{-1}\right)$ & 484.9 \\
\hline Fine sand $\left(\mathrm{g} \mathrm{kg}^{-1}\right)$ & 30.8 \\
\hline Corse sand $\left(\mathrm{g} \mathrm{kg}^{-1}\right)$ & 30.3 \\
\hline Texture & Silty clay \\
\hline Organic carbon $\left(\mathrm{g} \mathrm{kg}^{-1}\right)$ & 8.64 \\
\hline $\mathrm{CaCO}_{3}\left(\mathrm{~g} \mathrm{~kg}^{-1}\right)$ & 12.5 \\
\hline $\mathrm{EC}_{(1: 2.5)}\left(\mathrm{dS} \mathrm{m}^{-1}\right)$ & 0.44 \\
\hline $\mathrm{pH}_{(1: 1)}$ & 7.64 \\
\hline \multicolumn{2}{|l|}{ Soluble Cations in soil extract $(1: 2.5)$} \\
\hline $\mathrm{Ca}\left(\mathrm{cmol}_{\mathrm{c}} \mathrm{kg}^{-1}\right)$ & 0.5 \\
\hline $\operatorname{Mg}\left(\mathrm{cmol}_{\mathrm{c}} \mathrm{kg}^{-1}\right)$ & 0.28 \\
\hline $\mathrm{Na}\left(\mathrm{cmol}_{\mathrm{c}} \mathrm{kg}^{-1}\right)$ & 0.52 \\
\hline $\mathrm{K}\left(\mathrm{cmol}_{\mathrm{c}} \mathrm{kg}^{-1}\right)$ & 0.03 \\
\hline \multicolumn{2}{|l|}{ Exchangeable Cations } \\
\hline $\mathrm{Ca}\left(\mathrm{cmol}_{\mathrm{c}} \mathrm{kg}^{-1}\right)$ & 58.88 \\
\hline $\operatorname{Mg}\left(\mathrm{cmol}_{\mathrm{c}} \mathrm{kg}^{-1}\right)$ & 17.33 \\
\hline $\mathrm{Na}\left(\mathrm{cmol}_{\mathrm{c}} \mathrm{kg}^{-1}\right)$ & 1.3 \\
\hline $\mathrm{K}\left(\mathrm{cmol}_{\mathrm{c}} \mathrm{kg}^{-1}\right)$ & 1.58 \\
\hline Available phosphorus $\left(\mathrm{mg} \mathrm{kg}^{-1}\right)$ & 9.03 \\
\hline \multicolumn{2}{|c|}{ Farmyard manure } \\
\hline Organic carbon $\left(\mathrm{g} \mathrm{kg}^{-1}\right)$ & 128.5 \\
\hline Total $\mathrm{N}\left(\mathrm{g} \mathrm{kg}^{-1}\right)$ & 4.6 \\
\hline Total P $\left(\mathrm{g} \mathrm{kg}^{-1}\right)$ & 3 \\
\hline Total K $\left(\mathrm{g} \mathrm{kg}^{-1}\right)$ & 11 \\
\hline
\end{tabular}

Table 2: Olsen P, grain yield of corn, total phosphorus uptake (TPU), partial factor productivity of applied phosphorus (PFP), and crop recovery efficiency of applied phosphorus (REP) fertilized with sulfur and farmyard manure

\begin{tabular}{|c|c|c|c|c|c|}
\hline Treatment* & $\begin{array}{l}\text { Olsen P } \\
\left(\mathrm{mg} \mathrm{kg}^{-1}\right)\end{array}$ & $\begin{array}{l}\text { Grain yield } \\
\left(\mathrm{kg} \mathrm{ha}^{-1}\right)\end{array}$ & $\begin{array}{l}\text { TPU } \\
\left(\mathrm{kg} \mathrm{ha}^{-1}\right)\end{array}$ & $\begin{array}{l}\mathrm{PFPP} \\
\mathrm{kg} / \mathrm{kg} \mathrm{P}_{2} \mathrm{O}_{5}\end{array}$ & $\begin{array}{l}\text { REp } \\
\mathrm{kg} / \mathrm{kg}\end{array}$ \\
\hline SP & 12.4 & 4003.3 & 20.5 & 111.2 & 0.04 \\
\hline $\mathrm{SP}+\mathrm{S}$ & 14.5 & 4919.6 & 24.9 & 136.7 & 0.16 \\
\hline $\mathrm{SP}+\mathrm{FYM}$ & 20.9 & 5790.2 & 30.4 & 160.9 & 0.31 \\
\hline $\mathrm{SP}+\mathrm{FYM}+\mathrm{S}$ & 22.5 & 5774.6 & 29.1 & 160.4 & 0.28 \\
\hline LSD $_{0.05}$ & 5.89 & 763.6 & 4.23 & 21.20 & 0.109 \\
\hline
\end{tabular}

$\mathrm{SP}=$ superphosphate, $\mathrm{SP}+\mathrm{S}=$ sulfur + superphosphate, $\mathrm{SP}+\mathrm{FYM}=$ farmyard manure + superphosphate

$\mathrm{SP}+\mathrm{FYM}+\mathrm{S}=$ sulfur + farmyard manure + superphosphate 


\section{Partial factor productivity and crop recovery efficiency of applied phosphorus}

The results in this study showed that the amendment through farmyard manure and sulfur with superphosphate improved the partial factor productivity of applied phosphorus $\left(\mathrm{PFP}_{\mathrm{P}}\right)$ or phosphorus use efficiency in comparison with superphosphate alone (Table 2). $\mathrm{PFP}_{\mathrm{P}}$ was increased from $111.2 \mathrm{~kg}$ of corn grain $/ \mathrm{kg}$ of $\mathrm{P}_{2} \mathrm{O}_{5}$ applied for superphosphate treatment to 160.9 and $160.4 \mathrm{~kg}$ of corn grain $/ \mathrm{kg}$ of $\mathrm{P}_{2} \mathrm{O}_{5}$ for superphosphate + farmyard manure and superphosphate + farmyard manure + sulfur, respectively. It has been well documented that sulfur and farmyard manure applications with superphosphate caused significant increases in the crop recovery efficiency of applied phosphorus $\left(R_{P}\right)$. Increasing in the $R_{P}$ was noticed from $0.04 \mathrm{~kg} \mathrm{P}$ uptake/kg applied $\mathrm{P}_{2} \mathrm{O}_{5}$ at $\mathrm{SP}$ to 0.31 and $0.28 \mathrm{~kg} \mathrm{P}$ uptake/kg applied $\mathrm{P}_{2} \mathrm{O}_{5}$ for $\mathrm{SP}+\mathrm{FYM}$ and $\mathrm{SP}+\mathrm{FYM}+\mathrm{S}$ treatments, respectively (Table 2).

\section{Discussion}

\section{Effect of sulfur and farmyard manure on Olsen P}

In this study, the application of sulfur and farmyard manure with superphosphate to the soil resulted in an increase in Olsen $\mathrm{P}$ by $81.4 \%$ compared to superphosphate treatment. Therefore, these treatments resulted in increases in the soil available phosphorus in the order of $\mathrm{SP}+\mathrm{FYM}+\mathrm{S}>\mathrm{SP}+\mathrm{FYM}>\mathrm{SP}+\mathrm{S}>\mathrm{SP}$. The concentration of available phosphorus increases because of the applications of manure with phosphate fertilizer (Zhihui et al., 2016). The phosphorus availability is enhanced as a result of the decomposition of organic manure which releases nutrients such as phosphorus (Galvez-Sola et al., 2010) as well as lowering the soil $\mathrm{pH}$ due to sulfur and FYM addition. Applying sulfur with triple superphosphate was reported to show significantly higher available-P than using triple superphosphate alone in alkaline high-Ca soils may be because the addition of elemental sulfur produces sulfuric acid that is created by microbial oxidation of sulfur (DeLuca, 1989). The combined application of organic manure and chemical fertilizers also could increase the availability of soil phosphorus (Ding et al., 2016).

\section{Effect of sulfur, farmyard manure and their mixture on corn plant parameters}

Compared to the superphosphate treatment, additions of $\mathrm{SP}+\mathrm{FYM}, \mathrm{SP}+\mathrm{FYM}+\mathrm{S}$ and $\mathrm{SP}+\mathrm{S}$ treatments displayed increases in the grain yield of 44.6, 44.2 and $22.9 \%$, respectively. Effectiveness of these treatments on the grain yield increase was in the order of SP+FYM> $\mathrm{SP}+\mathrm{FYM}+\mathrm{S}>\mathrm{SP}+\mathrm{S}>\mathrm{SP}$ (Figure 1). Applications of farmyard manure with triple superphosphate were found to exhibit a significant higher grain yield than adding triple superphosphate alone (Aye et al., 2009). Moreover, Rasool et al. (2008) indicated significant increases in the grain yield of corn due to the combined application of FYM and superphosphate. Also, the grain yield of corn increased with applying sulfur with inorganic fertilizers (Kihara and Njoroge, 2013). The increment of the grain yield may be attributed to the increases in the phosphorus availability with adding organic matter to the soil that improves the biological, physical and chemical soil properties which enhance plant growth and soil productivity (Zhao et al., 2009). Relative to the superphosphate treatment, SP+FYM, $\mathrm{SP}+\mathrm{FYM}+\mathrm{S}$ and $\mathrm{SP}+\mathrm{S}$ increased total phosphorus uptake by $48.5,42.2$ and $21.5 \%$, respectively. Effectiveness of the treatments in increasing the total phosphorus uptake by corn plants using the investigated treatments was in the order of $\mathrm{SP}+\mathrm{FYM}>\mathrm{SP}+\mathrm{FYM}+\mathrm{S}>\mathrm{SP}+\mathrm{S}>\mathrm{SP}$ (Fig. 1). These may be a result of the increase in the $\mathrm{P}$ availability of the soil and its absorption by plants. The uptake of phosphorus by corn plants increased with FYM and inorganic fertilizers additions over the control treatment (Rasool et al., 2008). Increases in the phosphorus uptake by corn roots and shoots were observed with increasing the phosphorus availability in the soil (Fageriaa and Baligar, 1997).

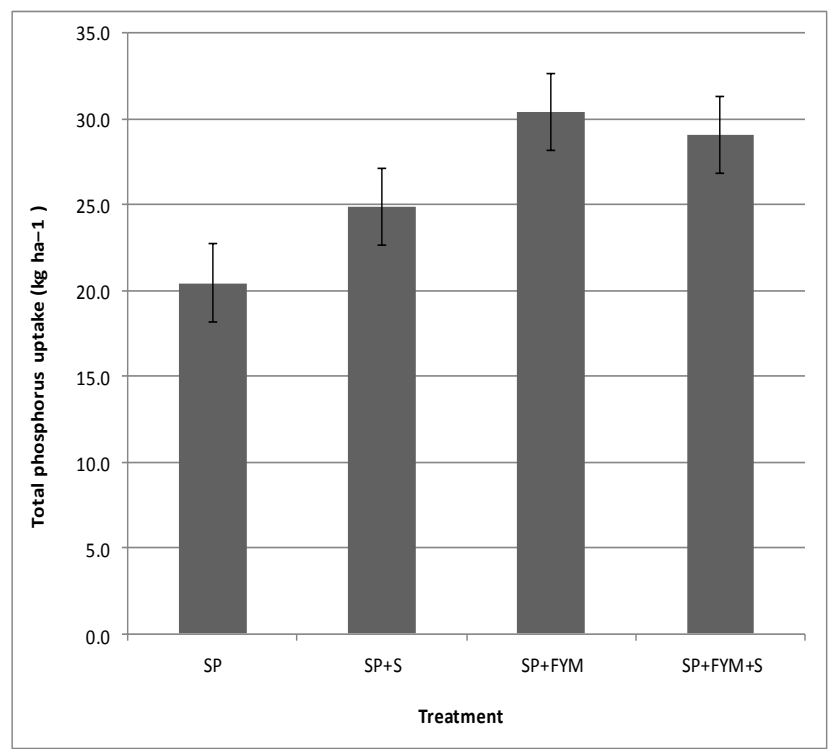

Figure 1: Changes of total phosphorus uptake by corn under amendment by sulfur and farmyard manure

Sulfur, farmyard manure and their mixture application with superphosphate increased the PFP $_{P}$ by $22.9,44.7$ and $44.2 \%$, respectively, relative to $\mathrm{SP}$ alone treatment. 
Therefore, the treatments used in this investigation showed increases in the PFPP in the order of $\mathrm{SP}+\mathrm{FYM}>$ $\mathrm{SP}+\mathrm{FYM}+\mathrm{S}>\mathrm{SP}+\mathrm{S}>\mathrm{SP}$ (Fig. 2). The increment of phosphorus use efficiency of corn plants may be due increase in the phosphorus availability of the soil (Fageriaa and Baligar, 1997). The highest value of $\mathrm{RE}_{\mathrm{P}}$ was recorded for farmyard manure with superphosphate treatment. The tested treatments can be ranked with respect of $R E_{P}$ increment in the order of $\mathrm{SP}+\mathrm{FYM}>\mathrm{SP}+\mathrm{FYM}+\mathrm{S}>\mathrm{SP}+\mathrm{S}>$ SP.

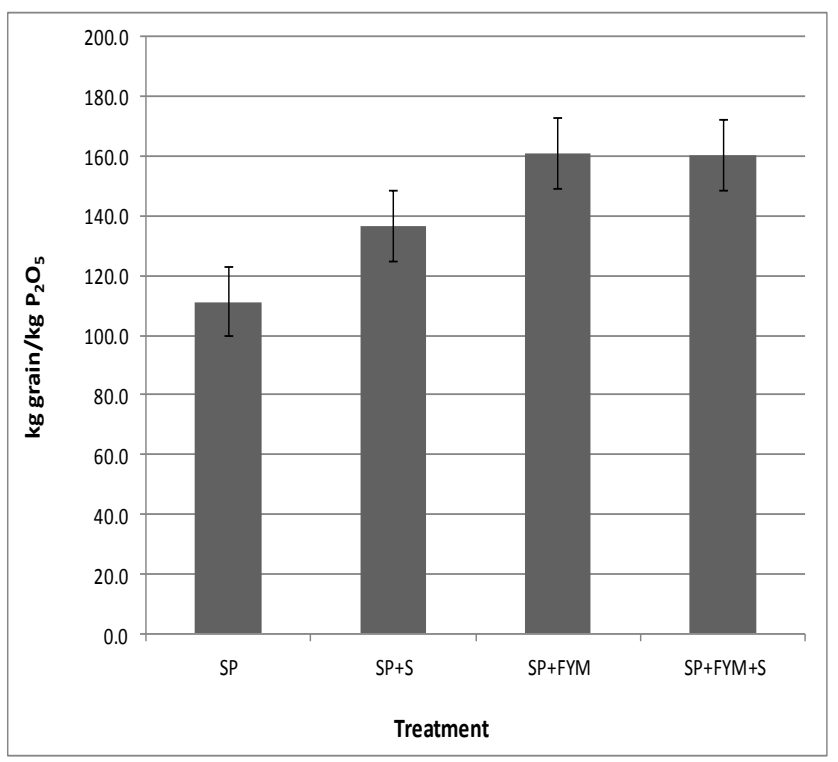

Figure 2: Partial factor productivity of applied phosphorus (PFP) affected by sulfur and farmyard manure amendments

\section{Conclusion}

In the current study, the application of sulfur and farmyard manure in the presence of superphosphate showed an improvement of the soil productivity by enhancing the bioavailability of phosphorus, grain yield of corn, total phosphorus uptake and use efficiency of phosphorus by corn plants. We recommend fertilizing the soil via sulfur and farmyard manure, this would be conducive to reduce the use of chemical fertilizers. This is considered one of the most important strategies of sustainable agriculture.

\section{Acknowledgments}

The author offers sincere thanks and appreciation to Prof. Dr. M.A. El-Desoky, Professor of Soil Sciences, Department of Soils and Water, Faculty of Agriculture, Assiut University, Egypt, for his linguistic correction of this manuscript.

\section{References}

Adediran, J.A., L.B. Taiwo, M.O. Akande, R.A. Sobulo and O.J. Idowu. 2005. Application of organic and inorganic fertilizer for sustainable maize and cowpea yields in Nigeria. Journal of Plant Nutrition 27: $1163-$ 1181.

Agbenin, J.O. and S.O. Igbokwe. 2006. Effect of soil-dung manure incubation on the solubility and retention of applied phosphate by a weathered tropical semi-arid soil. Geoderma 133: 191-203.

Aye, T.M., M.J. Hedley, P. Loganathan, R.D.B. Lefroy and N.S. Bolan. 2009. Effect of organic and inorganic phosphate fertilizers and their combination on maize yield and phosphorus availability in a Yellow Earth in Myanmar. Nutrient Cycling in Agroecosystems 83: 111-123.

Baligar, V.C., N.K. Fageria and Z.L. He. 2001. Nutrient use efficiency in plants. Communications in Soil Science and Plant Analysis 32: 921-950.

Baruah, T.C. and H.P. Barthakur. 1997. A Textbook of soil analysis. Vikas Publishing House PVT LTD, New Delhi, India.

Bhatti, T.M. and W. Yawar. 2010. Bacterial solubilization of phosphorus from phosphate rock containing sulfurmud. Hydrometallurgy 103: 54-59.

Brady, N.C. and R.R. Weil. 1999. The Nature and Properties of Soils. 12th Ed. Prentice-Hall International, Inc., Upper Saddle River, NJ., USA.

DeLuca, T.H., E.O. Skogley and R.E. Engel. 1989. Bandapplied elemental sulfur to enhance the phytoavailability of phosphorus in alkaline calcareous soils. Biology and Fertility of Soils 7: 346-350.

Ding, J., X. Jiang, D. Guan, B. Zhao, M. Ma, B. Zhou, F. Cao, X. Yang, L. Li and J. Li. 2016. Influence of inorganic fertilizer and organic manure application on fungal communities in a long-term field experiment of Chinese Mollisols. Applied Soil Ecology 111: 114-122.

Dobermann, A.R. 2005. Nitrogen use efficiency - State of the Art" (2005). Agronomy, Horticulture - Faculty Publications. $316 \mathrm{p}$.

Edmeades, D.C. 2003. The long-term effects of manures and fertilisers on soil productivity and quality: A review. Nutrient Cycling in Agroecosystems 66: 165180.

Fageria, N.K.. and V.C.Baligar. 1997. Phosphorus- use efficiency by corn genotypes. Journal of Plant Nutrition 20: 1267-1277.

Frossard, E., E. Bünemann, J. Jansa, A. Oberson and C. Feller. 2009. Concepts and practices of nutrient management in agro-ecosystems: Can we draw lessons from history to design future sustainable agricultural production systems? Die Bodenkult 60: 43-60. 
Galvez-Sola, L., J. Morales, A.M. Mayoral, F.C. Marhuenda-Egea, E. MartinezSabater, M.D. PerezMurcia, M.A. Bustamante, C. Paredes and R. Moral. 2010. Estimation of phosphorus content and dynamics during composting: Use of near infrared spectroscopy. Chemosphere 78: 13-21.

Garg, S. and G.S. Bahl. 2008. Phosphorus availability to maize as influenced by organic manures and fertilizer $\mathrm{P}$ associated phosphatase activity in soils. Bioresource Technology 99: 5773-5777.

Hussein, A.H.A. 2009. Phosphorus use efficiency by two varieties of corn at different phosphorus fertilizer application rates. Research Journal of Applied Sciences 4: 85-93.

Jackson, M.L. 1973. Soil chemical analysis. Prentice-Hall, Inc., Englewood Cliffs. N.J. New Delhi.

Khan, M.J., M.H. Khan, R.A. Khattak and M.T. Jan. 2006. Response of maize to different levels of sulfur. Communications in Soil Science and Plant Analysis 37: 41-51.

Kihara, J. and S. Njoroge. 2013. Phosphorus agronomic efficiency in maize-based cropping systems: A focus on western Kenya. Field Crops Research 150: 1-8.

Morais, J.F.V. and N.A. Rabelo. 1986. A simple plant tissue digestion method. EMBRAPA-CNPAF, Document No. 12, Goiania, Brazil.
Olsen, S.R., C.V. Cole, F.S. Watanabe and L.A. Dean. 1954. Estimation of available phosphorus in soils by extraction with sodium bicarbonate. Circular/United States Department of Agriculture (no. 939).

Rasool, R., S.S. Kukal and G.S. Hira. 2008. Soil organic carbon and physical properties as affected by long-term application of FYM and inorganic fertilizers in maizewheat system. Soil and Tillage Research 101: 31-36.

Steel, R. G. D. and J. H. Torrie. 1982. Principles and Procedures of Statistics a Biometrical Approach. Mc Graw Hill Book Company, New York. USA.

Zhao, Y., P. Wang, J. Li, Y. Chen, X. Ying, and S. Liu. 2009. The effects of two organic manures on soil properties and crop yields on a temperate calcareous soil under a wheat-maize cropping system. European Journal of Agronomy 31: 36-42.

Zhihui, W., S. Jianbo, M. Blackwell, L. Haigang, Z. Bingqiang and Y. Huimin. 2016. Combined applications of nitrogen and phosphorus fertilizers with manure increase maize yield and nutrient uptake via stimulating root growth in a long-term experiment. Pedosphere 26: 62-73. 